\title{
Meltem
}

\section{Oruç Aruoba}

"Komşu" olan iki dilde de aynı sözcük, hele aynı anlamda bulunuyorsa, önemli olan sözcük hangisinden hangisine gelmiş sorusu değil, bu iki dil nerede komşu olmuşlar sorusudur.

İşte, Türkçe ve Grekçe, epey bir süre komşu olmak bir yana, bir arada yaşadıklarına göre nerede bir arada yaşamışlardır sorusu daha önemli olur. İstanbul'da tabii ki, ama ondan önce İzmir'de - o zaman soru, sözcük orada ne anlama gelir olur. Yani anlamı birbirlerine nerede aktarmışlardır sorusu. $O$ zaman, belki anlam o yerden kaynaklanmıştır diyebiliriz.

Öyleyse, "meltem", İzmir'de ne anlama gelir diye soralım. Sözlükler, açımlayıcı olmaktan çok kapayıcı... Ama biliyoruz ki "imbat" gibi "meltem" de denizden karaya eser. Aralarında yalnızca "şiddet" farkı vardır, yön değil. "İmbat" "güçlü", "meltem" ise adından anlaşıldığı gibi "mülayim"dir. İkisi de, kara-deniz ısı farklarından dolayı denizden karaya doğru eser.

Neyse, biz sözlük anlamlarına boş verip, yerlere bakalım:

Bugünkü İzmir'in "Çin Seddi" haline getirilmiş "Birinci Kordon"unu alaıım: Yüksek bir duvar halinde 11-13 kat yükselen, birbirine bitişik, bu "apartman"lar, daha 70 (diyelim) yıl önce, bahçe içinde "köşk”lerdi. (Biz bugün eski fotoğraflardan biliyoruz.) Denize karşı bahçelerinden iki yanlarından, kara içlerine doğru, İkinci Kordon'a (?) doğru eser, serinlik getirirdi. (Bir anıma izin olsun: Yıllar önce Aliağa Rafinerisi'nin inşaatçı firmasının genel müdürünün oturduğu en üst katta bulunduğum olmuştu: Evinde air-condition gerekmezdi; sabah erken kalkıp, merakından dolayı limandaki gemi trafiğini izlerdi. Teksaslı bir çeyrek apaçiydi Robert Davies.)

Bugün, artık bu "Çin Seddi", hem fiziki (beton) varlığıyla, hem de finansiyel (rant) varlığıyla baş edilemez bir gerçeklik olarak "orada" olduğuna göre, İzmir'in bugünkü ve gelecekteki "yerel yöneticileri" için bir "kentsel sorun" olmaya devam edecektir - ne diyelim: Allah kolaylık versin!

Buradaki bu "yayın", adını bu karmaşadan alan Meltem dergisi de umuyorum buna benzer bir "kolaylık" bulur...

Oyunlar Köyü, İzmir, Kasım 2016 